\title{
AN EMPIRICAL STUDY OF IMPULSIVE CONSUMERS' BEHAVIOUR AT THE TIME OF SELECTION OF FMCG PRODUCTS DUE TO DEMONETISATION: A FACTOR
}

ANALYSIS

\section{Mr. Prashant Ravindrakumar Pandya \\ Dr. Kerav Pandya}

\begin{abstract}
:
With the carrying out of Demonetization, The Government has been hopeful the vision of cashless society in India, advancing the people to apply various cashless option like Credit/Debit Card, EWallet, Cheque, Online transfer-NEFT/RTGS, Demand Draft, Mobile Wallet-PAYTM etc in their routine life. An impulsive buying is made unconsciously and usually without regard to costs or harmful consequences. They are usually provoked by the need for instant self-satisfaction. The study is based on the primary data collected from retail malls like Big Bazaar, Reliance Fresh, D Mart and Osia Mall in Ahmedabad City with the help of structured questionnaire. Data analysis has been done using SPSS software. The statistical analysis method employed in this study is Factor Analysis and Chi Square analysis. For the present study, 170 mall shoppers were selected from malls of Ahmedabad city. The research is focusing on factors which affect Impulsiveness of Consumers' Behaviour at the Time of Selection of FMCG Products due to demonetisation. The study also find out that majority of the customers are affecting
\end{abstract}

Keywords: Demonetization, Impulse Buying Behavior, FMCG products

\section{Introduction to Study:}

Impulsive buying could be defined as the "spontaneous and unreflective desires to buy, without thoughtful consideration of why and for what reason a person should have the product" (Vohs \& Faber, 2007). In their book Handbook of Self-Regulation Vohs and Baumeister (2011) have identified three characteristics of impulsive buying: (1) rapid decision to buy, (2) diminished concern for the consequences, (3) the decision to buy emerges between a conflict between affect (desire) and cognition (control). Most of the time, before impulsive purchases are made, there would be a sense of 
doubt in whether a purchase should be made or not. However, due to the spontaneity of impulsive buying, that doubt becomes a mere fleeting thought that is not paid attention to.

Demonetization is the act of stripping a currency unit of its status as legal tender. Demonetisation is necessary whenever there is a change of national currency. The old unit of currency must be retired and replaced with a new currency unit. The demonetisation was done in an effort to stop the counterfeiting of the current banknotes alleged to be used for funding terrorism and for cracking down on black money in the country.

In contrast to the belief that impulse buying is a recent concept, the studies related to impulse buying started in the 1950s. Studies conducted during this period defined impulse buying as "unplanned" purchases and designed within this framework. But Dennis Rook (1987) points out that impulse buying implies a narrower and more specific range of phenomena than unplanned purchasing does. He states that; "impulse buying occurs when consumers experience sudden, generally powerful and persistent urge to buy something immediately".

In the past, demonetizations were taken after the independence of India. In January 1946, currency notes of `1000 and `10,000 rupees were withdrawn and new notes of `1000, `5000 and `10,000 rupees were reintroduced in 1954.The Janata Party coalition government had again demonetized notes of $` 1000$, ` 5000 and `10,000 rupees on 16 January 1978 as a means to curb forgery and black money. On 28 October 2016, the total currency in circulation in India was ` 17.77 lakh crore (US\$260 billion). In terms of value, the annual report of Reserve Bank of India of 31 March 2016 stated that total bank notes in circulation valued to ` 16.42 lakh crore (US\$240 billion) of which nearly $86 \%$ (i.e. ' 14.18 lakh crore (US\$210 billion)) was ` 500 and ` 1000 rupee notes. In terms of volume, the report stated that $24 \%$ (i.e. ' 2,203 crore) of the total ` $9,026.6$ crore banknotes were in circulation. Zimbabwe, USA, Australia, Myanmar, North Korea, Pakistan, Nigeria are country tried to demonetization of their country.

\section{Review of Literature:}

Impulse buying prior to 1982 focused on the product rather than the consumer as the motivator of impulse purchases. For instance, Stern (1962) provides the foundation for defining impulse buying behavior, which classifies the act as planned, unplanned, or impulse. According to this scheme, planned buying behavior involves a time-consuming information search followed by rational decision making (Piron, 1991; Stern, 1962). Unplanned buying refers to all purchases made without such 
advance planning and includes impulse buying, which is distinguished by the relative speed with which buying decisions occur. Impulse buying occurs when a consumer experiences a sudden, often powerful and persistent urge to buy something immediately. The impulse to buy is hedonically complex and may stimulate emotional conflict. Also, impulse buying is prone to occur with diminished regard for its consequences (Rook, 1987, p. 191).

The announcement of Demonetisation was made by the Prime Minister of India Narendra Modi in a live televised address to the nation at exact 8:15 pm IST the same day. In the announcement, Modi declared circulation of all 500 and 1000 rupee banknotes (approximately $\$ 7.50$ and \$15 USD respectively) of the Mahatma Gandhi series as invalid and announced the issuance of 500 and 2000 rupee banknotes in the new Mahatma Gandhi series in exchange for the old banknotes. The demonetisation was done in an effort to stop the counterfeiting of the current banknotes alleged to be used for funding terrorism and for cracking down on black money in the country.PM announced that existing ` 500 or ` 1,000 notes can be deposited in an individual's bank or post office accounts between November 10 and December 30.Currency value of up to `4,000 can be exchanged from any bank or post office per day till November 24 by showing a government identity card. There will, however, be an overall limit on withdrawal from banks of `10,000 per day and `20,000 per week, which will be increased in the coming days.

FMCG (Fast Moving Consumer Goods) is also known as consumer packaged goods. Items in this category include all consumables (other than groceries/pulses) people buy at regular intervals. The most common in the list are toilet soaps, detergents, shampoos, toothpaste, shaving products, shoe polish, packaged foodstuff, and household accessories and extends to certain electronic goods (cells). These items are meant for daily or frequent consumption and have a high return. Their shelf life is low and daily usability is high. FMCG is a compulsory purchase without which the day to day activities of normal household activities are dependent on.

In FMCG Industry, more than 80-85\% transactions between retailers to distributors are cash based. Further though most of the large FMCG companies do not extend credit to distributors, but distributors tend to extend credit to retailers typically for a period ranging between 7 days to 3 weeks. Under-reporting of sale at retailer level and transactions without bill by distributors is a rampant practice in trade and is something ignored by FMCG players being off book. All this money which used to typically find its way back in circulation has been made redundant by the governments move. The money which is genuine was also stuck since majority of it is in denominations of Rs 500 or Rs 1000 and the process of conversion is tedious and with a limit of Rs 4000 per day. These transactions being high value in nature was seen taking time before the order is re-established. Distributors for 
Impulse products like beverage and chocolates are usually non -exclusive. This would mean that for a distributor with lower liquidity his preference might force him to divert his limited cash to products which have a high throughput and turnover ratio i.e. either consumer staples or personal care.

\section{Objective:}

The main objective of the study is to understand consumers' behavior on demonetization and also to study of various factors which affects Impulsive consumers' behaviour due to Demonetisation with reference to age, gender, educational qualification, occupation.

\section{Research Methodology:}

Survey approach was used for gathering primary data and research questionnaire was used for the research. The questionnaire was designed using Likert Scale. Total 220 respondents of Ahmedabad city from various malls are selected collected from Customers \& Visitors of retail malls like Big Bazaar, Reliance Fresh, D Mart and Osia Mall in Ahmedabad City, Out of those 170 valid responses are used for analysis purpose.

\section{Data Analysis and Discussion}

\section{Factor Analysis}

One of the most widely used interdependency techniques for data reduction is factor analysis. Factor analysis seeks to identify a set of dimensions that is not readily observed in a large set of variables.

Factor analysis is multivariate statistical technique which is used to summarize the information contained in a large number of variables into a smaller number of subsets of factors (Hair et al., 2003). Also there are several reasons for using factors analysis as follows: (i) to identify a new, smaller set of uncorrelated variables to replace the original set of correlated variables, (ii) to identify a smaller set of salient variables from a larger set, and (iii) to identify underlying dimensions or factors, that explain the correlations among a set of variables (Malhotra, 2003)

\begin{tabular}{|l|l|r|}
\hline \multicolumn{2}{|c|}{ Table: 1 KMO and Bartlett's Test } & .779 \\
\hline Kaiser-Meyer-Olkin Measure of Sampling Adequacy. & $\begin{array}{l}\text { Approx. Chi- } \\
\text { Square }\end{array}$ & 414.985 \\
\cline { 2 - 3 } Bartlett's Test of Sphericity & df & 45 \\
\cline { 2 - 3 } & Sig. & .000 \\
\hline
\end{tabular}

Looking at the Table1, the KMO measure is 0.779 hence it is inferred that the sample size is adequate for the factor analysis. Bartlett's test shows the p-value as 0.000 for the chi square statistic (414.985) at 45 degrees of freedom and hence the factor analysis could be further proceeds for the reduction of 
the factors and identify the key factors influencing impulsive buying behaviour in the FMCG segment influence by the demonetization. Therefore, it is established from the statistical measures that the variables have some correlation and therefore, factor analysis is appropriate.

Further analysis of factors shows that there are three factors can be extracted based on the Eigen values as the mentioned following table shows the same and conferred that three factors should be extracted and having an influence on the buying behaviour in the FMCG and which also influenced by the effect of demonetization

\begin{tabular}{|c|c|c|c|c|c|c|}
\hline \multicolumn{7}{|c|}{ Table: 2 Total Variance Explained } \\
\hline & \multicolumn{3}{|c|}{ Initial Eigen values } & \multicolumn{3}{|c|}{ Extraction Sums of Squared Loadings } \\
\hline Component & Total & $\begin{array}{c}\% \text { of } \\
\text { Variance }\end{array}$ & $\begin{array}{c}\text { Cumulative } \\
\% \\
\end{array}$ & Total & $\begin{array}{c}\% \text { of } \\
\text { Variance }\end{array}$ & $\begin{array}{c}\text { Cumulative } \\
\% \\
\end{array}$ \\
\hline 1 & 3.194 & 31.943 & 31.943 & 3.194 & 31.943 & 31.943 \\
\hline 2 & 1.452 & 14.522 & 46.464 & 1.452 & 14.522 & 46.464 \\
\hline 3 & 1.252 & 12.520 & 58.984 & 1.252 & 12.520 & 58.984 \\
\hline 4 & .934 & 9.339 & 68.323 & & & \\
\hline 5 & .845 & 8.450 & 76.774 & & & \\
\hline 6 & .635 & 6.346 & 83.120 & & & \\
\hline 7 & .574 & 5.743 & 88.862 & & & \\
\hline 8 & .476 & 4.755 & 93.618 & & & \\
\hline 9 & .336 & 3.362 & 96.980 & & & \\
\hline 10 & .302 & 3.020 & 100.000 & & & \\
\hline \multicolumn{7}{|c|}{ Extraction Method: Principal Component Analysis. } \\
\hline
\end{tabular}

First factor extracted above having the highest Eigen value which is 3.194 which depicts the highest loaded factor in the factor analysis. Further, more the component 2 and 3 also bearing the Eigen value more than 1 so these factor could be extracted and studied further to check the influence of demonetization on the impulsive buying behaviour of the consumers in the FMCG Segments.

\begin{tabular}{|l|c|c|c|}
\hline \multicolumn{3}{|c|}{ Table: 3 Component Matrix a } \\
\hline & \multicolumn{3}{|c|}{ Component } \\
\cline { 2 - 4 } & 1 & 2 & 3 \\
\hline Do you have any problem of getting cash from Bank or ATM? & .367 & -.526 & .492 \\
\hline Do you think demonetisation will affect your shopping? & .569 & -.544 & .165 \\
\hline $\begin{array}{l}\text { Do you think demonetization will help in cashless transaction to } \\
\text { buy FMCG products? }\end{array}$ & .464 & .361 & -.043 \\
\hline $\begin{array}{l}\text { Do you think demonetisation will reduce your shopping expenses } \\
\text { on FMCG products due to non availability of hard cash? }\end{array}$ & .627 & -.326 & .042 \\
\hline $\begin{array}{l}\text { Do you think that price of FMCG will go down due to } \\
\text { demonetisation? }\end{array}$ & $\mathbf{. 6 5 8}$ & .225 & -.362 \\
\hline $\begin{array}{l}\text { Do you think that discounts and any other promotional schemes on } \\
\text { FMCG products will increase to attract consumer by retailers in } \\
\text { Demonetisation? }\end{array}$ & .614 & .319 & -.368 \\
\hline
\end{tabular}




\begin{tabular}{|l|c|c|c|}
\hline $\begin{array}{l}\text { Do you think that your expenses on FMCG products will } \\
\text { increase due to plastic cards? }\end{array}$ & $\mathbf{. 6 9 4}$ & -.203 & -.223 \\
\hline $\begin{array}{l}\text { Do you think that expenses on FMCG products will go up due } \\
\text { to any other cashless option? }\end{array}$ & $\mathbf{. 6 6 4}$ & -.085 & -.221 \\
\hline $\begin{array}{l}\text { Have you prepared well planned budget or disciplinary budget for } \\
\text { spending of FMCG products? }\end{array}$ & .501 & .364 & .532 \\
\hline $\begin{array}{l}\text { Do you think that demonetization will help in track your expenses } \\
\text { easily on FMCG products? }\end{array}$ & .379 & .556 & .575 \\
\hline \multicolumn{2}{|c|}{ Extraction Method: Principal Component Analysis. } \\
\hline
\end{tabular}

From the Component matrix it can be identified that, expenses on FMCG products will increase due to plastic cards bearing the highest loading on the factor plot which is 0.694 and has been placed on component 1 so it contains the highest impact on the FMCG buying behaviour. Next factor, expenses on FMCG products will go up due to any other cashless option bearing the factor loading 0.664 and placed on the component one. And finally third factor, price of FMCG will go down due to demonetisation with a factor loading of 0.658 could be extracted and studied further to assess the impact of demonetization on the impulsive buying behaviour.

Chi Square Test to Assess the Demographic influence on Impulsive buying Behvaiour

$\mathrm{H}_{1}=$ Age of the respondents having significant influence on Impulsive buying behaviour

Table 4 Age V/s. Factors Chi Square

\begin{tabular}{|l|c|c|}
\hline \multicolumn{1}{|c|}{ Factors } & Value & Significance \\
\hline $\begin{array}{l}\text { Do you think demonetization will help in cashless transaction to buy } \\
\text { FMCG products? }\end{array}$ & 15.974 & 0.192 \\
\hline $\begin{array}{l}\text { Do you think demonetisation will reduce your shopping expenses on } \\
\text { FMCG products due to non availability of hard cash? }\end{array}$ & 11.619 & 0.477 \\
\hline Do you think that price of FMCG will go down due to demonetisation? & 20.151 & 0.041 \\
\hline $\begin{array}{l}\text { Do you think that discounts and any other promotional schemes on FMCG } \\
\text { products will increase to attract consumer by retailers in Demonetisation? }\end{array}$ & 13.107 & 0.361 \\
\hline $\begin{array}{l}\text { Do you think that your expenses on FMCG products will increase due to } \\
\text { plastic cards? }\end{array}$ & 17.053 & 0.044 \\
\hline $\begin{array}{l}\text { Do you think that expenses on FMCG products will go up due to any } \\
\text { other cashless option? }\end{array}$ & 19.781 & 0.035 \\
\hline $\begin{array}{l}\text { Have you prepared well planned budget or disciplinary budget for } \\
\text { spending of FMCG products? }\end{array}$ & 12.825 & 0.382 \\
\hline
\end{tabular}

Chi Square statics mentioned in the above table 4 shows the summary of the chi square results of Age and Impulsive buying behvaiour. Further the analysis shows that Buyers mindset about fall in prices 
of FMCG products due to demonetization varies as per the age and age is the factor which influence on the Impulsive buying behvaiour of the respondents in FMCG market as chi square value is 20.151 which is significant (0.041) at the level of significance of 0.05 . Further expenses on FMCG products will increase due to plastic cards having significance value 0.044 and expenses on FMCG products will go up due to any other cashless option with a significance value 0.035 . These are the factors influenced by the age of the respondents

\section{$\mathrm{H}_{2}=$ Gender of the respondents having significant influence on Impulsive buying behaviour}

Table 5 Gender V/s. Factors Chi Square

\begin{tabular}{|l|c|c|}
\hline \multicolumn{1}{|c|}{ Factors } & Value & Significance \\
\hline Do you think demonetisation will affect your shopping? & 9.304 & 0.054 \\
\hline $\begin{array}{l}\text { Do you think demonetization will help in cashless transaction to buy } \\
\text { FMCG products? }\end{array}$ & 5.611 & 0.23 \\
\hline $\begin{array}{l}\text { Do you think demonetisation will reduce your shopping expenses on } \\
\text { FMCG products due to non availability of hard cash? }\end{array}$ & 12.614 & 0.013 \\
\hline Do you think that price of FMCG will go down due to demonetisation? & 13.28 & 0.01 \\
\hline $\begin{array}{l}\text { Do you think that discounts and any other promotional schemes on FMCG } \\
\text { products will increase to attract consumer by retailers in Demonetisation? }\end{array}$ & 12.913 & 0.12 \\
\hline $\begin{array}{l}\text { Do you think that your expenses on FMCG products will increase due to } \\
\text { plastic cards? }\end{array}$ & 16.954 & 0.02 \\
\hline $\begin{array}{l}\text { Do you think that expenses on FMCG products will go up due to any other } \\
\text { cashless option? }\end{array}$ & 12.344 & 0.015 \\
\hline
\end{tabular}

Chi Square statics mentioned in the above table 5 shows the summary of the chi square results of gender and Impulsive buying behvaiour. Further the analysis shows that demonetisation will reduce shopping expenses of buyers on FMCG products due to non availability of hard cash and gender having the significance value of 0.013 and chi square value of 12.614. Further price of FMCG will go down due to demonetisation is the factor of the Impulsive buying behvaiour of the respondents in FMCG market having chi square value is 13.28 which is significant $(0.01)$ at the level of significance of 0.05. Moving further, expenses on FMCG products will increase due to plastic cards having significance value 0.02 and expenses on FMCG products will go up due to any other cashless option with a significance value 0.015 . These are the factors influenced by the gender of the respondents

$\mathrm{H}_{3}=$ Educational qualification of the respondents having significant influence on Impulsive buying behaviour

Table 6 Educational Qualification V/s. Factors Chi Square Factors Value $\quad$ Significance 
Do you think demonetisation will affect your shopping?

Do you think demonetization will help in cashless transaction to buy FMCG products?

Do you think demonetisation will reduce your shopping expenses on FMCG products due to non availability of hard cash?

Do you think that price of FMCG will go down due to demonetisation?

Do you think that discounts and any other promotional schemes on FMCG products will increase to attract consumer by retailers in Demonetisation?

Do you think that your expenses on FMCG products will increase due to plastic cards?

Do you think that expenses on FMCG products will go up due to any other cashless option?

\begin{tabular}{|l|l|}
18.491 & 0.102 \\
\hline 14.151 & 0.029 \\
\hline 22.188 & 0.035 \\
\hline 9.466 & 0.003 \\
\hline 3.414 & 0.992 \\
\hline 12.987 & 0.037 \\
\hline 19.335 & 0.081 \\
\hline
\end{tabular}

Chi Square statics mentioned in the above table 6 shows the summary of the chi square results of educational qualification and Impulsive buying behvaiour. Further the analysis shows that demonetisation will reduce shopping expenses of buyers on FMCG products due to non availability of hard cash and education having the significance value of 0.003 and chi square value of 9.46. Further price of FMCG will go down due to demonetisation is the factor of the Impulsive buying behvaiour of the respondents in FMCG market having chi square value is 12.987 which is significant $(0.037)$ at the level of significance of 0.05 . Continuing further demonetisation reduce the shopping expenses on FMCG products due to non availability of hard cash having a significance value 0.035 . These are the factors influenced by the educational qualification of the respondents

\section{$\mathrm{H}_{4}=$ Occupation of the respondents having significant influence on Impulsive buying behaviour}

Table 7 Occupation V/s. Factors Chi Square

\begin{tabular}{|l|c|c|}
\hline \multicolumn{1}{|c|}{ Factors } & Value & Significance \\
\hline $\begin{array}{l}\text { Do you think demonetization will help in cashless transaction to buy } \\
\text { FMCG products? }\end{array}$ & 13.384 & 0.644 \\
\hline $\begin{array}{l}\text { Do you think demonetisation will reduce your shopping expenses on } \\
\text { FMCG products due to non availability of hard cash? }\end{array}$ & 21.110 & 0.017 \\
\hline Do you think that price of FMCG will go down due to demonetisation? & 31.319 & 0.040 \\
\hline $\begin{array}{l}\text { Do you think that discounts and any other promotional schemes on FMCG } \\
\text { products will increase to attract consumer by retailers in Demonetisation? }\end{array}$ & 20.96 & 0.180 \\
\hline $\begin{array}{l}\text { Do you think that your expenses on FMCG products will increase due to } \\
\text { plastic cards? }\end{array}$ & 23.312 & 0.106 \\
\hline $\begin{array}{l}\text { Do you think that expenses on FMCG products will go up due to any other } \\
\text { cashless option? }\end{array}$ & 30.152 & 0.017 \\
\hline $\begin{array}{l}\text { Have you prepared well planned budget or disciplinary budget for spending } \\
\text { of FMCG products? }\end{array}$ & 13.297 & 0.651 \\
\hline $\begin{array}{l}\text { Do you think that demonetization will help in track your expenses easily on } \\
\text { FMCG products? }\end{array}$ & 13.04 & 0.67 \\
\hline
\end{tabular}


Chi Square statics mentioned in the above table 7 shows the summary of the chi square results of occupation and Impulsive buying behvaiour. Further the analysis shows that expenses on FMCG products will go up due to any other cashless option and occupation having the significance value of 0.017 and chi square value of 30.152. Further price of FMCG will go down due to demonetisation is the factor of the Impulsive buying behvaiour of the respondents in FMCG market having chi square value is 31.319. This is significant (0.040) at the level of significance of 0.05. Continuing further demonetisation reduce the shopping expenses on FMCG products due to non availability of hard cash having a significance value 0.017. These are the factors influenced by the occupation of the respondents

\section{Conclusion:}

From the result, it is concluded that with the affect of demonetization, people think that price of FMCG product will go down, expenses will go up due to usage of plastic card e.g. Debit and credit card and other cash less payment option like Mobile Wallet-PAYTM, Net Banking etc. Impulsive consumers feel that there will be reduction in their spending on FMCG products compared to situation before demonetisation because of non availability of hard cash with the customers. Some consumers make well planned budget for their spending, they can track easily their spending with the help of cashless system and also that discounts and any other promotional schemes on FMCG products will increase to attract consumer by retailers. 


\section{References:}

- Hair, Anderson, Tatham and Black (2006). "Multivariate Data Analysis”, Pearson education, Fifth edition

- Malhotra Naresh K. (2008). Marketing Research- An Applied Orientation, Pearson Education in South Asia, New Delhi

- Piron, F. (1991), “Defining impulse purchasing", Advances in Consumer Research, Vol. 18, pp. 509-13.

- Retrieved from http://hdl.handle.net/10603/76463 on 26.11.2017.

- Retrieved from http://www.investopedia.com/terms/d/demonetization.asp on 26.11.2017

- Retrieved from http://info.shine.com/industry/fmcg/6.html on 26.11.2017.

- Retrieved from https://www.linkedin.com/pulse/impact-demonetization-fmcg-industry-impulseproducts-raunakgokhale 26.11.2017.

- Rook, D.W. (1987), “The buying impulse”, Journal of Consumer Research, Vol. 14 No. 2, pp. 189199.

- Rook, D.W. and Fisher, R.J. (1995), "Normative influences on impulse buying behaviour”,Journal of Consumer Research, Vol.22 No. 3, pp. 305-313.

- Rook, D.W. and Gardner, M.P. (1993), "In the mood: impulse buying's affective antecedents", Research in Consumer Behaviour, Vol. 6 No. 7, pp. 1-28.

- Stern, H. (1962), “The significance of impulse buying today", Journal of Marketing, Vol. 26, April, pp. 59-63.

- Vohs, K.D. and Faber, R.J. (2007), "Spent resources: self-regulatory resource availability affects impulse buying”, Journal of Consumer Research, Vol. 33 No. 4, pp. 537-547.

\section{Mr. Prashant Ravindrakumar Pandya}

Research Scholar,

Gujarat Technological University, Ahmedabad.

Email: prpandya07@gmail.com, (M): +9199044 05943

$\boldsymbol{\&}$

Dr. Kerav Pandya, Associate Professor

C K Shah Vijapurwala Institute of Management, Vadodara.

Email: pandyakerav@yahoo.com, (M): +91 9427340666 